Jurnal Inkofar * Volume 1 No. 1 Juli 2019 * ISSN: 2615-3645 (Print) / 2581-2920 (Online)

Tersedia secara online di: http://www.politeknikmeta.ac.id/meta/ojs/

\title{
RANCANG BANGUN SISTEM INFORMASI PENJUALAN PERLENGKAPAN TIDUR (SIPPAT) BERBASIS WEB PADA FORTUN BAROKAH KARAWANG
}

\author{
Dian Ardiansyah $^{1}$, Walim Walim², Deni Gunawan ${ }^{3}$, Eka Fitriani ${ }^{4}$ \\ ${ }^{1}$ Pascasarjana Magister Ilmu Komputer / Sekolah Tinggi Manajemen Informatika dan Komputer \\ (STMIK) Nusa Mandiri / 14002094@nusamandiri.ac.id \\ ${ }^{2}$ Sistem Informasi / Teknologi Informasi / Universitas Bina Sarana Informatika / \\ walim.wam@bsi.ac.id \\ ${ }^{3}$ Sistem Informasi / Teknologi Informasi / Universitas Bina Sarana Informatika / deni.dee@bsi.ac.id \\ ${ }^{4}$ Sistem Informasi / Teknologi Informasi / Universitas Bina Sarana Informatika / \\ eka.ean@bsi.ac.id
}

\begin{abstract}
Fortun Barokah is a sleeping equipment sale, which focuses on service and quality of goods produced by the well. The difficulty of consumers to find the desired product and the difficulty of finding a media campaign. This led to the decrease of sales targets Barokah Fortun. The purpose of this study is to design an information system is web-based sales bedding. The method used in the Sales Information System Design Web-Based Equipment Sleeping on Fortun Barokah in knowing the running system is using a tool such as Entity Relationship Diagram (ERD), Logical Record Structure (LRS), navigation structure, and Testing Unit. Support software used is Macromedia Dreamweaver MX 2004 and for database use MySQL. The results showed the existence of this web-based system that is already connected to the database, of course, will greatly simplify the data pengolahaan items for sale and would be very helpful in terms of product marketing, for any information to be provided to consumers can more quickly and accurately.
\end{abstract}

Keywords: Sleeping Equipment Sales, Web

\begin{abstract}
ABSTRAK
Fortun Barokah merupakan tempat penjualan perlengkapan tidur yang memfokuskan pada pelayanan dan kualitas barang yang dihasilkan dengan baik. Sulitnya konsumen untuk mengetahui produk yang diinginkan dan sulitnya mencari media promosi. Hal tersebut menyebabkan semakin menurunnya target penjualan pada Fortun Barokah. Tujuan dilakukannya penelitian ini adalah untuk merancang sebuah sistem informasi penjualan perlengkapan tidur berbasis web. Metode yang digunakan dalam Perancangan Sistem Informasi Penjualan Perlengkapan Tidur Berbasis Web pada Fortun Barokah dalam mengetahui sistem yang sedang berjalan yaitu menggunakan alat bantu seperti Entity Relationship Diagram (ERD), Logical Record Structure (LRS), Struktur Navigasi, dan Pengujian Unit. Perangkat lunak pendukung yang digunakan adalah Macromedia Dreamweaver Mx 2004 dan untuk database menggunakan MySQL. Hasil penelitian menunjukan dengan adanya sistem berbasis web ini yang sudah terkoneksi dengan database, tentunya akan sangat mempermudah pengolahaan data barang untuk dijual dan akan sangat membantu sekali dalam hal pemasaran produk, karena setiap informasi yang akan diberikan kepada konsumen bisa lebih cepat dan akurat.
\end{abstract}

Kata Kunci: Penjualan Perlengkapan Tidur, Web

\section{PENDAHULUAN}

Fortun Barokah merupakan tempat penjualan perlengkapan tidur yang memfokuskan pada pelayanan dan kualitas barang yang dihasilkan dengan baik. Sulitnya konsumen untuk mengetahui produk yang diinginkan dan sulitnya mencari media promosi. Adanya sebuah sistem yang terkomputerisasi diharapkan akan memberikan kemudahan untuk mendapatkan informasi yang cepat dan akurat. Internet merupakan hal yang tidak tabu bagi setiap orang atau masyarakat, internet kini sudah menjadi konsumsi umum, baik di perkotaan, pedesaan, perkantoran maupun daerah pelosok, walau sebagian ada yang tidak tahu bahkan buta akan internet. Tapi kini internetpun sudah menjadi suatu yang bermanfaat dan bahkan menjadi kurikulum wajib dalam dunia pendidikan. Internet juga digunakan 
dalam dunia pemerintahan, bahkan internet bisa dijadikan ladang keuntungan bagi pengguna Internet. Banyaknya manfaat yang diperoleh menjadikan Internet suatu hal yang begitu penting untuk dipelajari. Penjualan perlengkapan tidur ini dibuat agar bisa menyebar ke seluruh masyarakat, paling tidak adanya penjualan secara online bisa memberikan informasi tentang bagaimana cara membeli perlengkapan tidur yang bermacam-macam bentuk dan model yang berbeda, murah dan lengkap. Penjualan perlengkapan tidur dengan cara online juga dapat meningkatkan hasil penjualan atau laba yang besar dibandingkan dengan cara lewat orang ke orang. Penjualan online atau yang sering kita sebut dengan E-Commerce adalah salah satu manfaat dari Internet, dimana kita bisa menjual, mempromosikan, memberikan jasa pada pengguna Internet lain, tanpa perlu bertatap muka, ijab qobul yang memakan waktu, negosiasi yang panjang serta meminimalisir waktu yang terbuang bagi penjual dan pembeli online. Maka Internet begitu bermanfaat bagi masyarakat salah satunya adalah $E$ Commerce. Ruang lingkup pembahasan yang dilakukan merancang website yang digunakan untuk penjualan perlengkapan tidur yang akan dipasarkan, sekaligus sebagai transaksi penjualan secara online. Seorang pengunjung hanya dapat melihat dan berinteraksi dengan tampilan yang disediakan di website kecuali melakukan transaksi pembelian, karena pengunjung harus melakukan pendaftaran terlebih dahulu untuk menjadi pelanggan/member. Pengunjung yang menjadi pelanggan bisa melakukan transaksi pembelian. Proses yang dapat di akses oleh admin adalah menambah data, mengubah data, menghapus data, melihat data dan melihat laporan data pengiriman.

\section{STUDI PUSTAKA}

Menurut (Sutarman, 2009) mengemukakan bahwa "E-Commerce adalah singkatan dari Electronic Commerce, yaitu pembelian, penjualan dan pertukaran barang atau layanan dan informasi secara elektronik, yaitu melalui jaringan komputer terutama internet". Beberapa macam ruang lingkup $E$ Commerce diantaranya sebagai berikut: Business to Business (B2B), Business to Consumers (B2C), Consumers to Consumers (C2C), Consumers to Business (B2C).

Menurut (Ardhana, 2012) menyatakan bahwa "Website adalah suatu layanan sajian informasi yang menggunakan konsep tautan (hyperlink), yang memudahkan surfer (sebutan para pemakai komputer yang melakukan browsing atau penelusuran informasi melalui internet)". Sejarah website dimulai pada tahun 1989, ketika Tim Berner-Lee seorang pekerja Laboratorium Fisika Partikel Eropa atau yang dikenal dengan nama Consei European pour Recherce Nuclaire (CERN) yang berada di Geneva, Swiss, mengajukan protokol sistem distribusi informasi internet yang digunakan untuk berbagi informasi antar fisikawan. Protokol inilah yang selanjutnya dikenal sebagai protokol world wide web dan dikembangkan oleh world wide web consortium (W3C). Pada awalnya web atau situs merupakan ruang atau halaman dalam internet yang menggunakan teknologi hypertext. Halaman tersebut digunakan untuk menampilkan informasi, gambar gerak, suara atau gabungan dari semua objek tersebut baik yang bersifat statis maupun dinamis yang membentuk suatu rangkaian bangunan yang terkait satu sama lain dengan link sebagai penghubung. Setiap pemakai dituntut untuk menemukan dengan mengikuti link yang di sediakan didalam dokumen web browser.

Menurut (Sadeli, 2013) menyatakan bahwa "Web Server adalah sebuah perangkat lunak yang berfungsi menerima permintaan HTTP dan HTTPS dari klien yang dikenal dengan sebuah web browser dan mengirimkan kembali hasilnya dalam bentuk halaman web yang umumnya berbentuk dokumen HTML". Contoh web server adalah Apache, Xampp, IIS, dll. Menurut (Ardhana, 2012) menyatakan bahwa "Web Browser adalah suatu program yang digunakan untuk membaca kode HTML yang kemudian menerjemahkannya kedalam bentuk visual". Contoh web browser adalah Internet Explorer, Firefox, Google Chrome, dll. Menurut (Wicaksono, 2008) menyatakan bahwa " $X A M P P$ adalah sebuah software yang berfungsi untuk menjalankan website berbasis $P H P$ dan menggunakan pengolah data $M y S Q L$ di komputer lokal". Menurut (Sugiarto, 2009) menyatakan bahwa "PHPMyAdmin adalah sebuah aplikasi dimana orang-orang dapat mengontrol data mereka dan isi web mereka untuk ditampilkan dalam sebuah website yang mereka buat".

Basis data atau Database menurut (Jogiyanto, 2009) mendefinisikan bahwa "Basis Data atau Database adalah kumpulan dari data yang saling berhubungan satu dengan lainnya, tersimpan diperangkat keras komputer dan digunakan diperangkat lunak untuk untuk manipulasinya”. Menurut (Ichwan, 2011) Basis Data (Database) adalah kumpulan data berelasi yang disusun, diorganisasikan dan disimpan secara sistematik dalam media simpan komputer mengacu kepada metode-metode tertentu sedemikian rupa sehingga dapat diakses secara cepat dan mudah menggunakan 
Jurnal Inkofar * Volume 1 No. 1 Juli 2019 * ISSN: 2615-3645 (Print) / 2581-2920 (Online)

Tersedia secara online di: http://www.politeknikmeta.ac.id/meta/ojs/

program/aplikasi komputer untuk memperoleh data dari basis data tersebut. Menurut (Virgi, 2011) menyatakan bahwa "MySQL adalah salah satu perangkat lunak sistem manajemen basis data (Database) SQL atau sering disebut dengan Database Management System (DBMS)". MySQL memiliki keslebihan yaitu bersifat multithread dan multiuser serta mendukung sistem jaraingan. MySQL bekerja dengan bahasa Structure Query Language (SQL) yang merupakan bahasa standar yang digunakan untuk manipulasi database. Pada umumnya perintah yang sering digunakan adalah mengambil (select), menambah (insert), mengubah (update) dan menghapus (delete).

Metode yang digunakan pada pengembangan perangkat lunak ini menggunakan model waterfall (Rosa and Shalahuddin, 2013) model waterfall sering juga disebut model sekuensial linier (sequential linear) atau alur hidup klasik (classic life cycle). Model waterfall menyediakan pendekatan alur hidup perangkat lunak secara sekuensial atau terurut dimulai dari analisis, desain, pengkodean, pengujian dan tahap pendukung (support).

Menurut (Fathansyah, 2004) Entity Relationship Diagram (ERD) merupakan model entity relationship yang berisi komponen-komponen himpunan entitas dan himpunan relasi yang masingmasing dilengkapi dengan atribut-atribut yang mempresentasikan seluruh fakta dari dunia nyata yang kita tinjau.

Menurut (Kroenke's, 2006) mengemukakan bahwa “ Logical Record Structure” (LRS) adalah representasi dari struktur record-record pada tabel-tabel yang terbentuk dari hasil relasi antar himpunan entitas. Di bentuk dengan nomor dan tipe record. Beberapa tipe record di gambarkan oleh kotak empat persegi panjang dan dengan nama yang unik.

Menurut (Suyanto, 2008) menyatakan bahwa "Struktur navigasi dalam situs web melibatkan sistem navigasi situs web secara keseluruhan dan desain interface situs web tersebut, navigasi memudahkan jalan yang mudah ketika menjelajahi situs web". Menurut (Binanto, 2010) bentuk dasar dari struktur navigasi adalah Linear (satu alur), Hierarchical (Hirarki), Non Linear (tidak berurutan) dan campuran.

Pengujian dilakukan dengan metode Black Box, karena dengan pengujian blackbox akan lebih mudah dan cepat untuk menguji fungsional perangkat lunak. Menurut (Janner, 2010) Rekayasa Perangkat Lunak klasifikasi black box testing adalah: Pengujian Fungsional (functional testing), Pengujian Tegangan (stress testing), Pengujian Beban (load testing), Pengujian Khusus (ad-hoc testing), Pengujian Penyelidikan (exploratory testing), Pengujian usability (usability testing), Pengujian Asap (smoke testing), Pengujian Pemulihan (recovery testing), Pengujian Volume (volume testing), Pengujian Domain (domain testing), Pengujian Skenario (scenario testing), Pengujian Regresi (regression testing), Penerimaan Pengguna (user acceptance), Pengujian Alfa (alpha testing), dan Pengujian Beta (beta testing).

\section{METODE PENELITIAN}

Dalam penelitian program Sistem Informasi Penjualan Perlengkapan Tidur (SIPPAT) Berbasis Web pada Fortun Barokah Karawang ini metode yang digunakan adalah:

3.1. Metode Pengembangan Perangkat Lunak

Model water fall (Rosa and Shalahuddin, 2013) model waterfall sering juga disebut model sekuensial linier (sequential linear) atau alur hidup klasik (classic life cycle). Model waterfall menyediakan pendekatan alur hidup perangkat lunak secara sekuensial atau terurut dimulai dari analisis, desain, pengkodean, pengujian dan tahap pendukung (support).

3.2. Teknik Pengumpulan Data

Teknik pengumpulan data yang dilakukan diantaranya adalah:

1. Metode Pengamatan (Observasi), mengadakan pengamatan langsung ke tempat objek penelitian untuk memperoleh keakuratan data terhadap proses Penjualan Perlengkapan Tidur Pada Fortun Barokah Karawang.

2. Metode Wawancara, dilakukan dengan cara tanya jawab secara langsung dengan pemilik dan karyawan Fortun Barokah Karawang agar dapat mengetahui permasalahan yang ada pada Fortun Barokah Karawang.

3. Metode Studi Pustaka, sumber data diperoleh dari buku-buku, makalah-makalah, artikelartikel dan referensi lain serta situs-situs internet sebagai landasan teori pengkajian bahan untuk menunjang penelitian. 


\section{HASIL PEMBAHASAN}

Fortun Barokah Karawang didirikan pada tanggal 20 April 1998 oleh Bapak Muhammad Sholeh yang terletak di Kampung Tegal Asem RT.14/RW.06 Desa Kertasari Kecamatan Rengasdengklok Kabupaten Karawang. Usaha ini bergerak dibidang manufaktur yaitu memproduksi kasur, bantal, guling dan bantalan kursi dengan memanfaatkan limbah busa sebagai bahan baku utamanya. Visi dari Fortun Barokah yaitu menjadikan Perusahaan yang terbaik dan terpercaya dengan mengutamakan kualitas, kejujuran, keramahan dan kerjasama yang berorientasi pada kepuasaan pelanggan. Adapun misi dari perusahaan ini memberikan pelayanan terbaik bagi konsumen dan menjalin kerjasama secara profesional, jujur dan tepat waktu dalam setiap kegiatan usaha dan mengutamakan kualitas kerja, produk dan hasil. Struktur Organisasi menggambarkan dengan jelas pemisahan kegiatan pekerjaan antara yang satu dengan yang lain dan bagaimana hubungan aktivitas dan fungsi dibatasi. Dalam struktur organisasi yang baik harus menjelaskan hubungan wewenang siapa melapor kepada siapa.

\subsection{Analisa Kebutuhan}

Langkah awal untuk menentukan perangkat lunak yang sesuai dengan kebutuhan pengguna.

\section{Kebutuhan Pengguna}

Program Penjualan Perlengkapan Tidur terdapat tiga pengguna yang dapat saling berinteraksi dalam lingkungan sistem yaitu Pengunjung, Pelanggan/Member, dan Admin. Kebutuhan informasi bagi pengguna tersebut adalah:

a. Kebutuhan Pengunjung

1) Pengunjung dapat melihat halaman Beranda

2) Pengunjung dapat melihat halaman Katalog

3) Pengunjung dapat melihat halaman Tentang Kami

4) Pengunjung dapat melihat halaman Testimonial

5) Pengunjung dapat melihat halaman Buku Tamu

6) Pengunjung dapat melihat halaman Kontak Kami

7) Pengunjung dapat melakukan pendaftaran pelanggan di halaman Daftar

8) Pengunjung dapat melihat halaman Cara Pembayaran

9) Pengunjung dapat melihat halaman Panduan Belanja

b. Kebutuhan Pelanggan/Member

1) Pelanggan dapat melakukan Login dan Logout Pelanggan

2) Pelanggan dapat melihat halaman Keranjang Belanja

3) Pelanggan dapat melihat dan mencetak daftar pemesanan di halaman Daftar Transaksi

4) Pelanggan dapat melakukan konfirmasi pembayaran di halaman Konfirmasi Pembayaran

5) Pelanggan dapat mengisi halaman Form Testimonial

6) Pelanggan dapat melihat halaman Beranda

7) Pelanggan dapat melihat halaman Katalog

8) Pelanggan dapat melihat halaman Tentang Kami

9) Pelanggan dapat melihat halaman Testimonial

10) Pelanggan dapat melihat halaman Kontak Kami

11) Pelanggan dapat melihat halaman Cara Pembayaran

12) Pelanggan dapat melihat halaman Panduan Belanja

c. Kebutuhan Admin
1) Admin dapat melakukan login dan logout Admin

2) Admin dapat mengelola data admin, data buku tamu, data testimonial, data barang, data pemesanan, konfirmasi transfer, dan laporan

3) Admin dapat mengelola data pemesanan barang dan mengubah status bayar yang awalnya "Pesan" menjadi "Kirim" apabila pelanggan sudah melakukan konfirmasi pembayaran.

\section{Kebutuhan Sistem}

a. Admin bertugas mengelola data admin, data buku tamu, data testimonial, data barang, data pemesanan, data konfirmasi transfer.

b. User dapat dengan mudah mendapatkan informasi mengenai produk dan penjualan pada website Fortun Barokah dengan mengakses website tersebut. Melalui website ini pula konsumen yang jauh dari Perusahaan dapat memperoleh informasi dengan mudah. 


\subsection{Entity Relationship Diagram (ERD)}

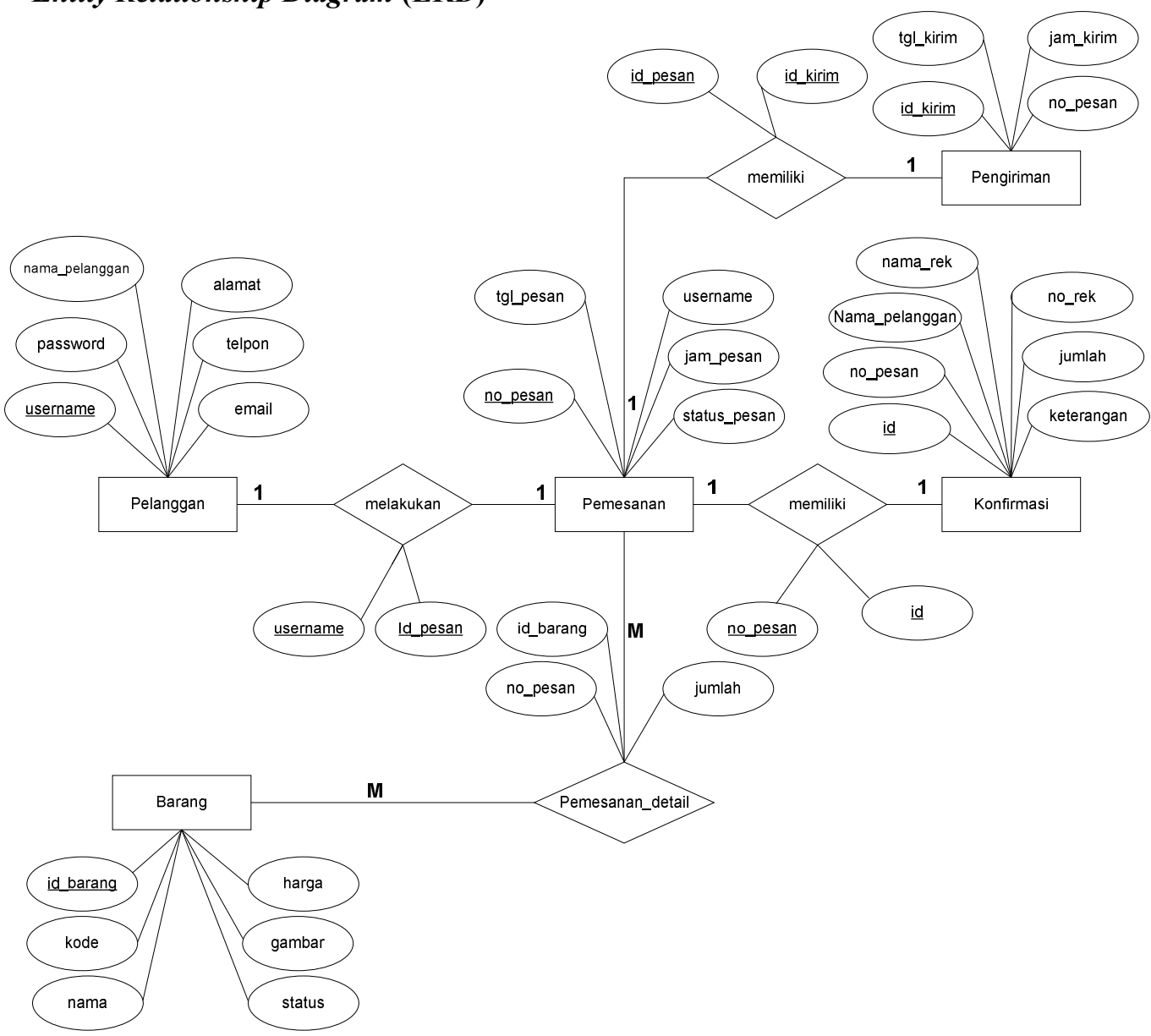

Gambar 1. ERD Sistem Informasi Penjualan Perlengkapan Tidur (SIPPAT)

\subsection{Logical Records Structure (LRS)}

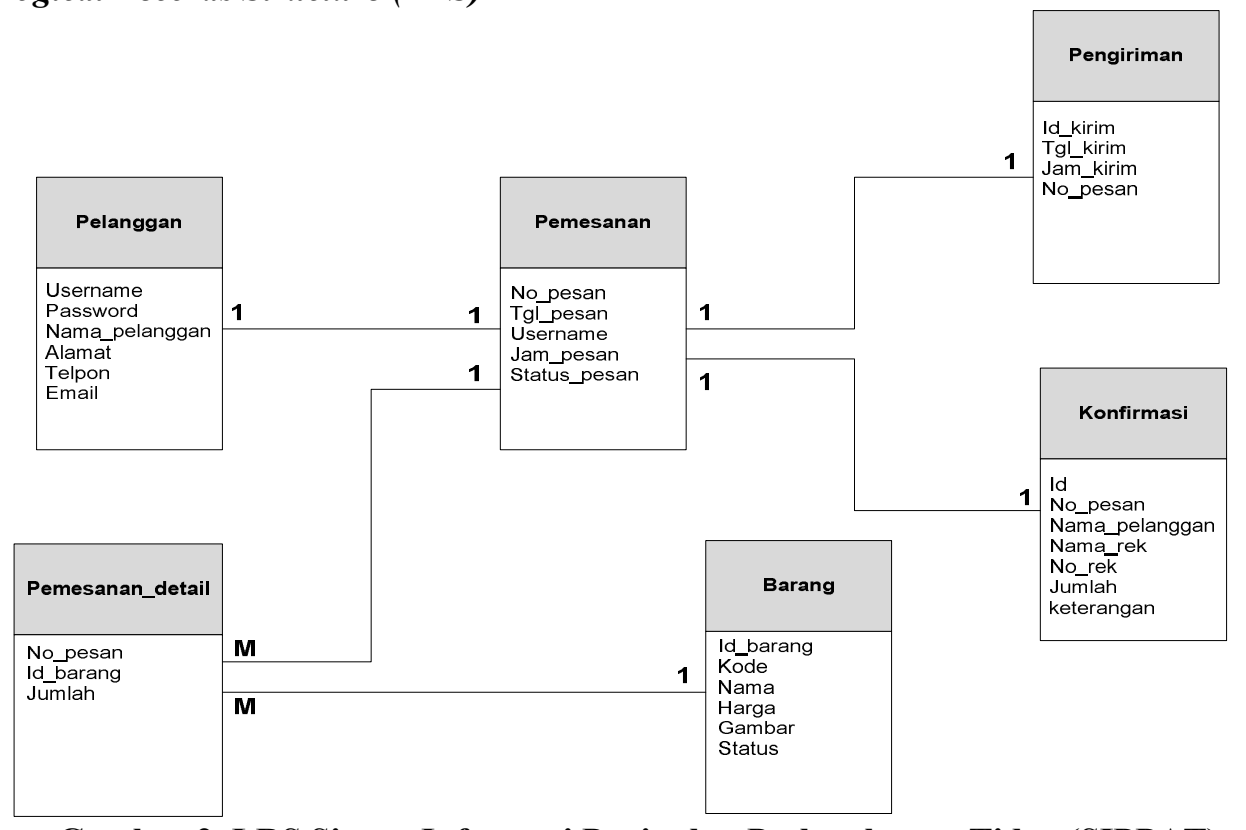

Gambar 2. LRS Sistem Informasi Penjualan Perlengkapan Tidur (SIPPAT) 


\subsection{Rancangan Struktur Navigasi}

Rancangan struktur navigasi dari program sistem informasi penjualan perlengkapan tidur (SIPPAT) diantaranya:

1. Rancangan Struktur Navigasi Pengunjung

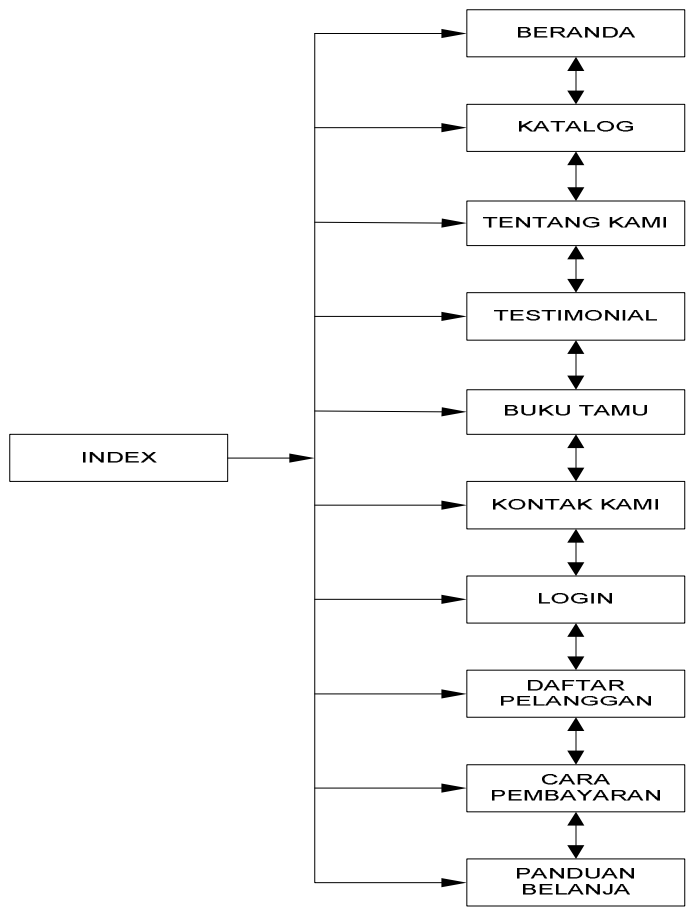

Gambar 3. Rancangan Struktur Navigasi Pengunjung

2. Rancangan Struktur Navigasi Pelanggan

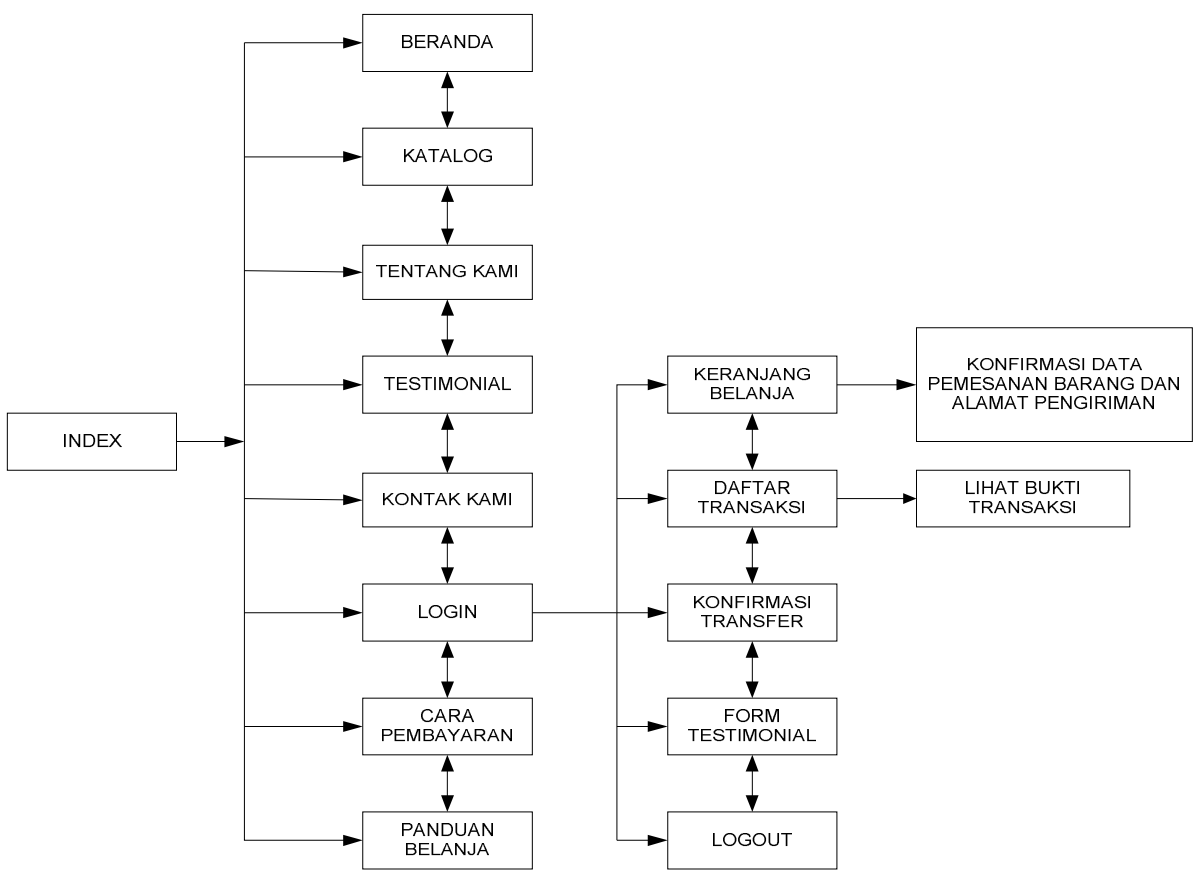

Gambar 4. Rancangan Struktur Navigasi Pelanggan 
3. Rancangan Struktur Navigasi Admin

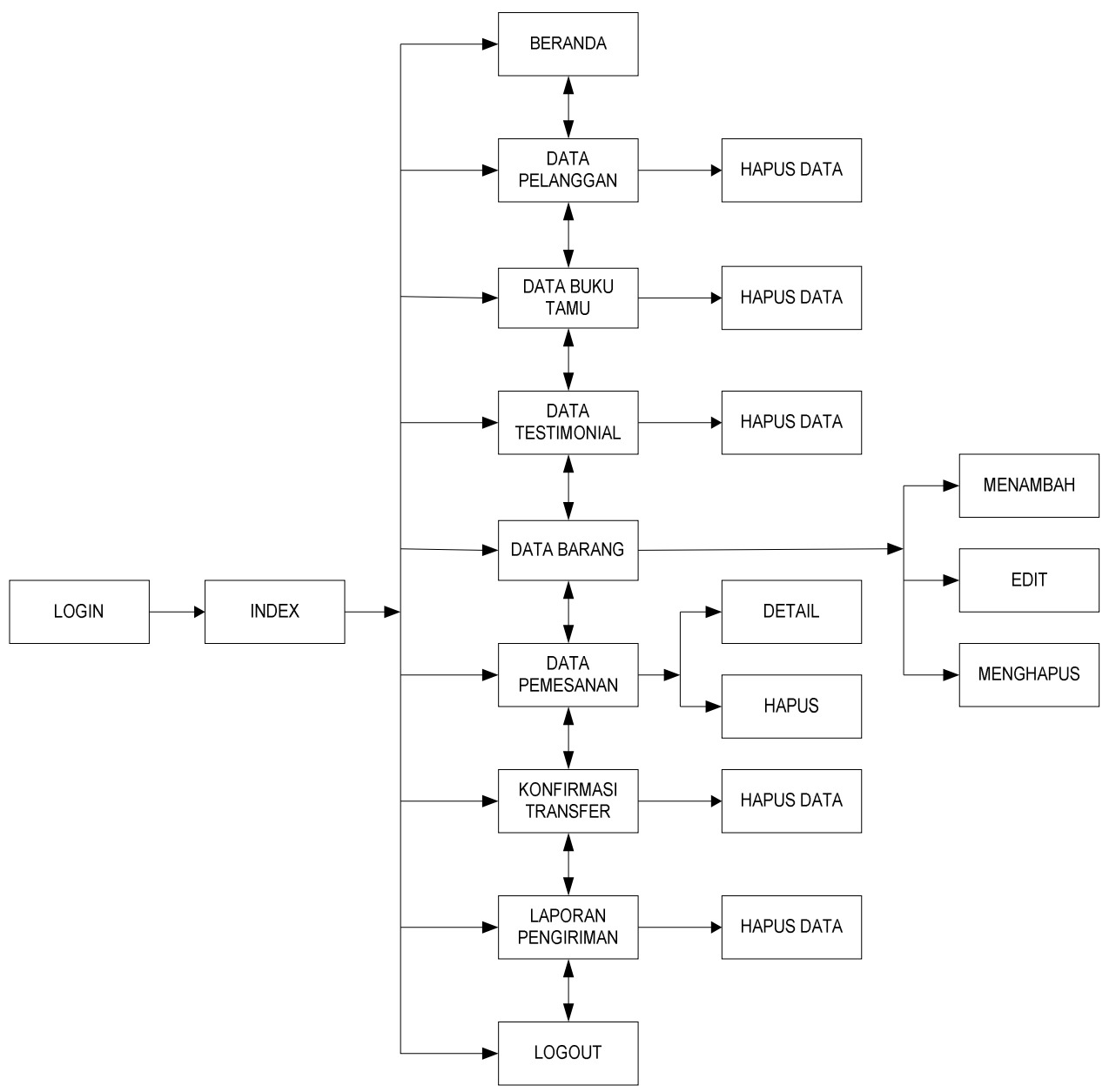

Gambar 5. Rancangan Struktur Navigasi Admin

\subsection{Implementasi Program}

1. Tampilan Halaman Pengunjung

a. Tampilan Menu Beranda

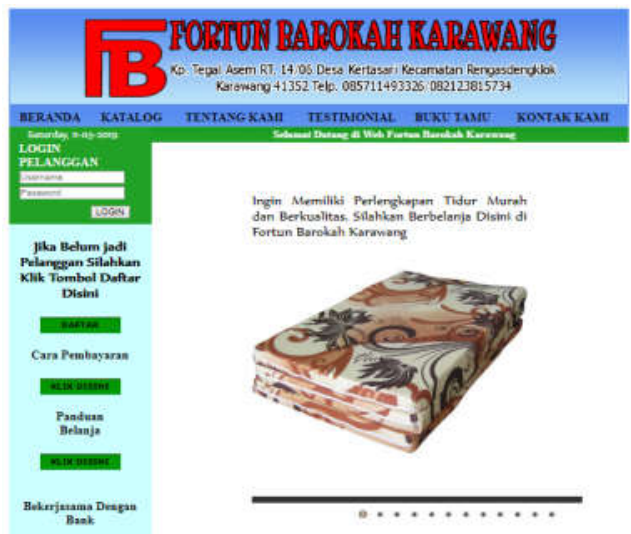

$\triangle B C A$

Gambar 6. Tampilan Menu Beranda 
b. Tampilan Menu Katalog

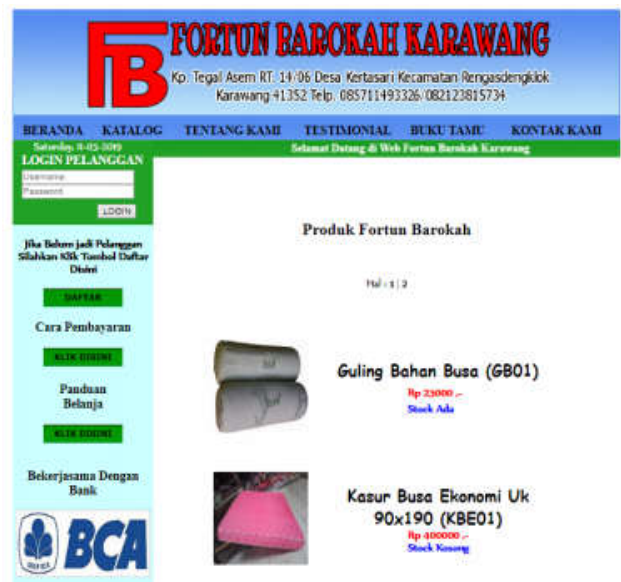

\section{Gambar 7. Tampilan Menu Katalog}

c. Tampilan Menu Tentang Kami

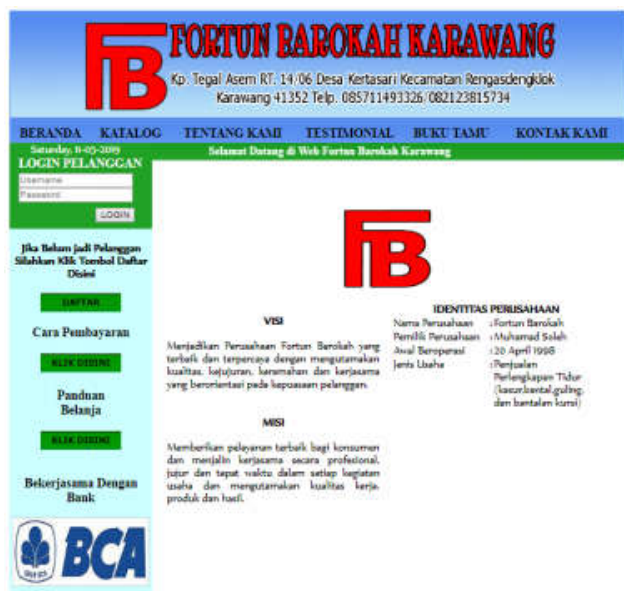

Gambar 8. Tampilan Menu Tentang Kami

2. Tampilan Halaman Pelanggan

a. Tampilan Menu Login Pelanggan

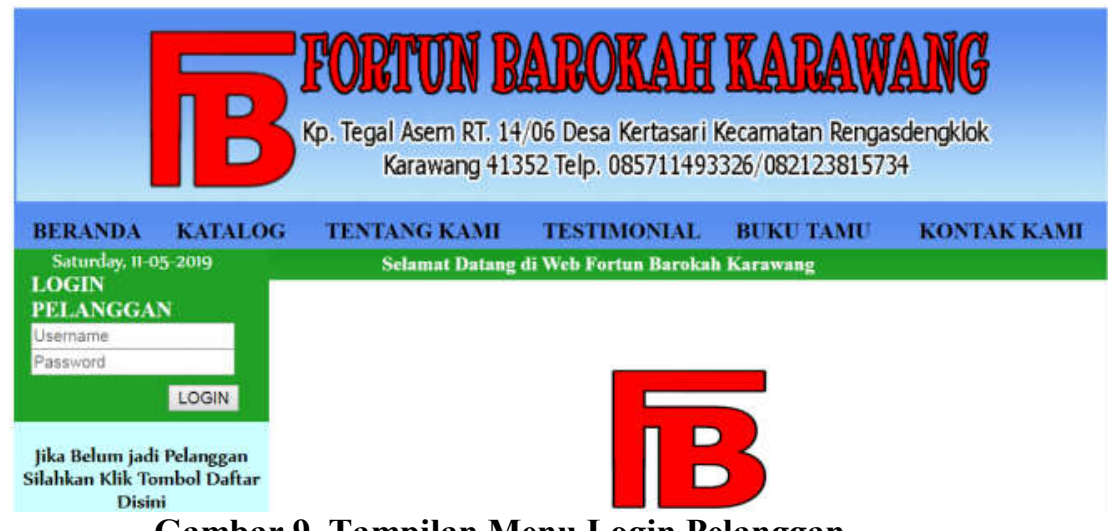

Gambar 9. Tampilan Menu Login Pelanggan 
b. Tampilan Menu Keranjang Belanja

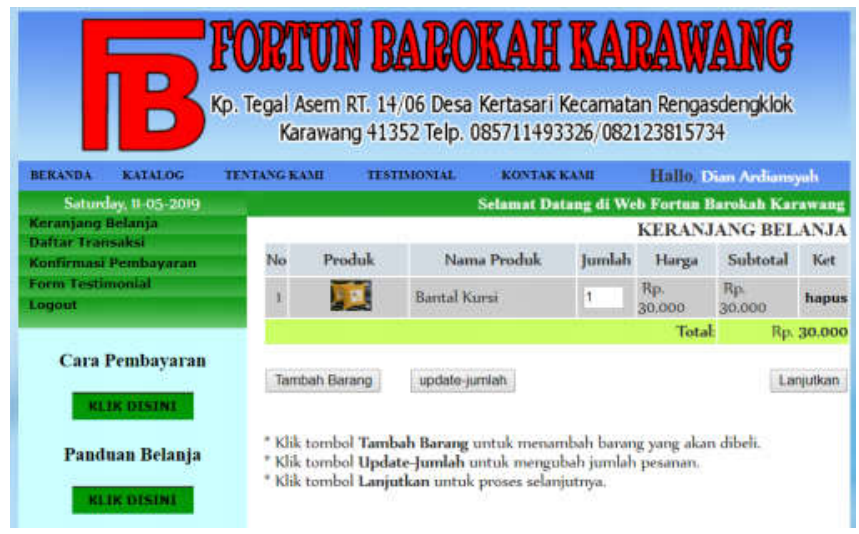

Gambar 10. Tampilan Menu Keranjang Belanja

c. Tampilan Menu Daftar Transaksi

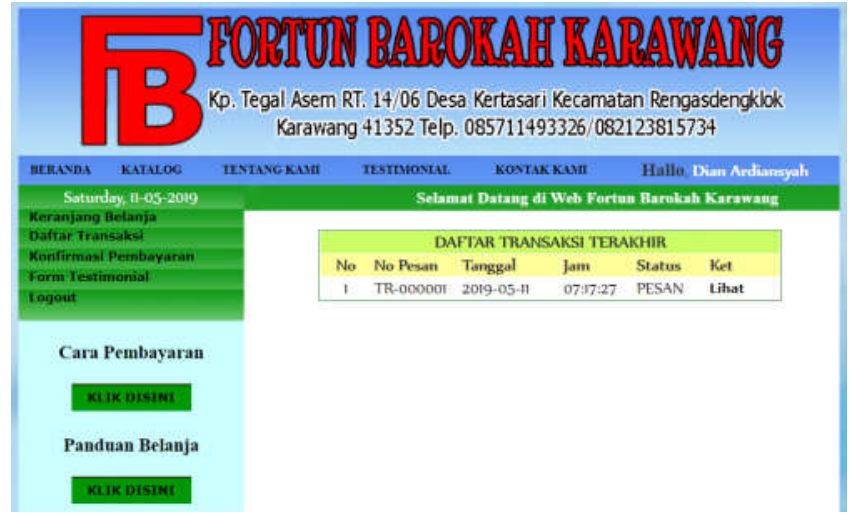

Gambar 11. Tampilan Menu Daftar Transaksi

3. Tampilan Halaman Admin

a. Tampilan Menu Data Barang

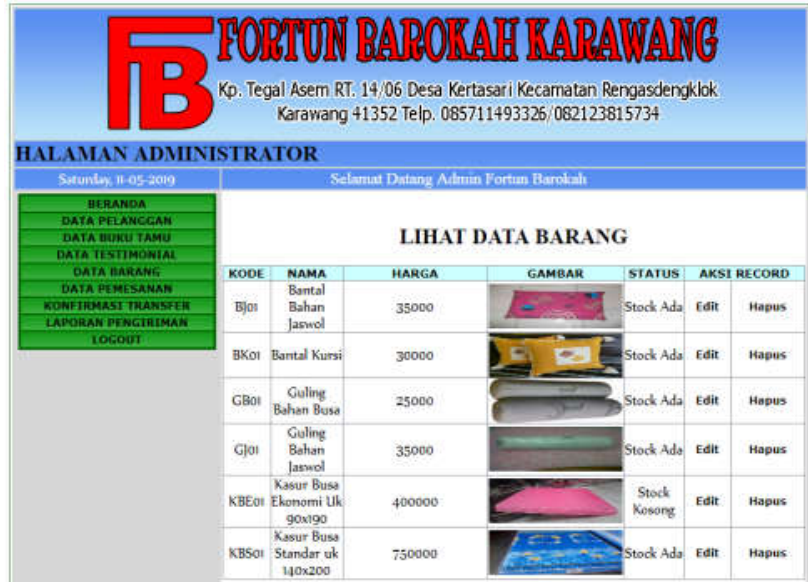

Gambar 12. Tampilan Menu Data Barang 
b. Tampilan Menu Konfirmasi Pembayaran

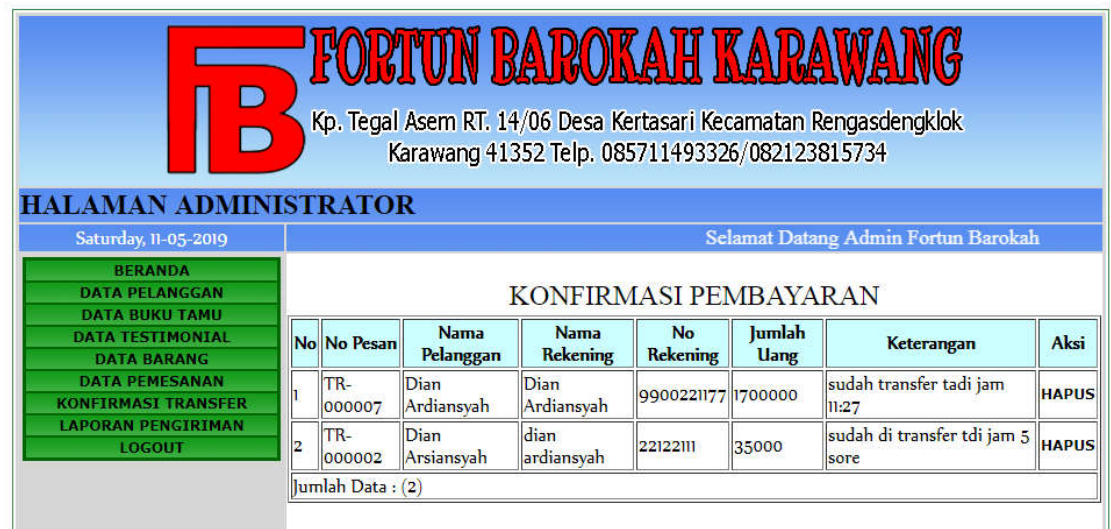

Gambar 13. Tampilan Menu Konfirmasi Pembayaran

\subsection{Pengujian Unit}

Tabel 1. Pengujian Black Box Testing Halaman Daftar Pelanggan

\begin{tabular}{|c|c|c|c|c|c|}
\hline No & $\begin{array}{c}\text { Skenario } \\
\text { Pengujian }\end{array}$ & Test case & $\begin{array}{l}\text { Hasil yang } \\
\text { diharapkan }\end{array}$ & $\begin{array}{c}\text { Hasil } \\
\text { pengujian }\end{array}$ & Kesimpulan \\
\hline 1. & $\begin{array}{l}\text { Mengisi } \\
\text { username } \\
\text { dan } \\
\text { mengosongk } \\
\text { an password, } \\
\text { nama } \\
\text { Lengkap, } \\
\text { alamat, no } \\
\text { telp/HP, } \\
\text { email } \\
\text { kemudian } \\
\text { klik tombol } \\
\text { submit }\end{array}$ & $\begin{array}{l}\text { Username: dian } \\
\text { Password: (kosong) } \\
\text { Nama Lengkap: (kosong) } \\
\text { Alamat: (kosong) } \\
\text { NoTelp/HP: (kosong) } \\
\text { Email: (kosong) }\end{array}$ & $\begin{array}{l}\text { Sistem akan } \\
\text { menolak } \\
\text { akses } \\
\text { pendaftaran } \\
\text { dan } \\
\text { menampilka } \\
\text { n "Data } \\
\text { yang anda } \\
\text { masukkan } \\
\text { masih ada } \\
\text { yang } \\
\text { kosong" }\end{array}$ & $\begin{array}{c}\text { Sesuai } \\
\text { harapan }\end{array}$ & Valid \\
\hline 2. & $\begin{array}{l}\text { Mengisi } \\
\text { password } \\
\text { dan } \\
\text { mengosongk } \\
\text { an username, } \\
\text { nama } \\
\text { Lengkap, } \\
\text { alamat, no } \\
\text { telp/Hp, } \\
\text { email, } \\
\text { kemudian } \\
\text { klik tombol } \\
\text { submit }\end{array}$ & $\begin{array}{l}\text { Username: (kosong) } \\
\text { Password: dian } \\
\text { Nama Lengkap: (kosong) } \\
\text { Alamat: (kosong) } \\
\text { No Telp: (kosong) } \\
\text { Email: (kosong) }\end{array}$ & $\begin{array}{l}\text { Sistem akan } \\
\text { menolak } \\
\text { akses } \\
\text { pendaftaran } \\
\text { dan } \\
\text { menampilka } \\
\text { n "Data } \\
\text { yang anda } \\
\text { masukkan } \\
\text { masih ada } \\
\text { yang } \\
\text { kosong" }\end{array}$ & $\begin{array}{c}\text { Sesuai } \\
\text { harapan }\end{array}$ & Valid \\
\hline 3. & $\begin{array}{l}\text { Mengisi } \\
\text { password, } \\
\text { username, } \\
\text { dan } \\
\text { mengosongk } \\
\text { an nama }\end{array}$ & $\begin{array}{l}\text { Username: dian } \\
\text { Password: dian } \\
\text { Nama Lengkap: (kosong) } \\
\text { Alamat: (kosong) } \\
\text { No Telp: (kosong) } \\
\text { Email: (kosong) }\end{array}$ & $\begin{array}{l}\text { Sistem akan } \\
\text { menolak } \\
\text { akses } \\
\text { pendaftaran } \\
\text { dan } \\
\text { menampilka }\end{array}$ & $\begin{array}{l}\text { Sesuai } \\
\text { harapan }\end{array}$ & Valid \\
\hline
\end{tabular}




\begin{tabular}{|c|c|c|c|c|c|}
\hline & $\begin{array}{l}\text { lengkap, } \\
\text { alamat, no } \\
\text { telp, email, } \\
\text { kemudian } \\
\text { klik tombol } \\
\text { submit }\end{array}$ & & $\begin{array}{l}\mathrm{n} \text { "Data } \\
\text { yang anda } \\
\text { masukkan } \\
\text { masih ada } \\
\text { yang } \\
\text { kosong" }\end{array}$ & & \\
\hline 4. & $\begin{array}{l}\text { Mengisi } \\
\text { password, } \\
\text { username, } \\
\text { nama } \\
\text { Lengkap dan } \\
\text { mengosongk } \\
\text { an alamat, no } \\
\text { telp, email, } \\
\text { kemudian } \\
\text { klik tombol } \\
\text { submit }\end{array}$ & $\begin{array}{l}\text { Username: dian } \\
\text { Password: dian } \\
\text { Nama: Dian Ardiansyah } \\
\text { Alamat: (kosong) } \\
\text { No Telp: (kosong) } \\
\text { Email: (kosong) }\end{array}$ & $\begin{array}{l}\text { Sistem akan } \\
\text { menolak } \\
\text { akses } \\
\text { pendaftaran } \\
\text { dan } \\
\text { menampilka } \\
\text { n "Data } \\
\text { yang anda } \\
\text { masukkan } \\
\text { masih ada } \\
\text { yang } \\
\text { kosong" }\end{array}$ & $\begin{array}{c}\text { Sesuai } \\
\text { harapan }\end{array}$ & Valid \\
\hline 5. & $\begin{array}{l}\text { Mengisi } \\
\text { password, } \\
\text { username, } \\
\text { nama } \\
\text { Lengkap } \\
\text { alamat dan } \\
\text { mengosongk } \\
\text { an No telp, } \\
\text { email, } \\
\text { kemudian } \\
\text { klik tombol } \\
\text { submit }\end{array}$ & $\begin{array}{l}\text { Username: dian } \\
\text { Password: dian } \\
\text { Nama: Dian Ardiansyah } \\
\text { Alamat: Karawang } \\
\text { Telp: (kosong) } \\
\text { Email: (kosong) }\end{array}$ & $\begin{array}{l}\text { "Data yang } \\
\text { anda } \\
\text { masukkan } \\
\text { masih ada } \\
\text { yang } \\
\text { kosong" }\end{array}$ & $\begin{array}{c}\text { Sesuai } \\
\text { harapan }\end{array}$ & Valid \\
\hline 6. & $\begin{array}{l}\text { Mengisi } \\
\text { password, } \\
\text { username, } \\
\text { nama } \\
\text { lengkap } \\
\text { alamat, no tlp } \\
\text { dan } \\
\text { mengosongk } \\
\text { an email, } \\
\text { kemudian } \\
\text { klik tombol } \\
\text { submit }\end{array}$ & $\begin{array}{l}\text { Username: dian } \\
\text { Password: dian } \\
\text { Nama: dian ardiansyah } \\
\text { Alamat: Karawang } \\
\text { Telp: 085882722509 } \\
\text { Email: (kosong) }\end{array}$ & $\begin{array}{l}\text { "Data yang } \\
\text { anda } \\
\text { masukkan } \\
\text { masih ada } \\
\text { yang } \\
\text { kosong" }\end{array}$ & $\begin{array}{c}\text { Sesuai } \\
\text { harapan }\end{array}$ & Valid \\
\hline 7. & $\begin{array}{l}\text { Mengisi } \\
\text { password, } \\
\text { username, } \\
\text { nama } \\
\text { lengkap, } \\
\text { alamat, no } \\
\text { telp dan } \\
\text { email } \\
\text { kemudian } \\
\text { klik tombol } \\
\text { submit }\end{array}$ & $\begin{array}{l}\text { Username: dian } \\
\text { Password: dian } \\
\text { Nama: dian ardiansyah } \\
\text { Alamat: Karawang } \\
\text { Telp: 085882722509 } \\
\text { Email: } \\
\text { 14002094@nusamandiri@bsi.a } \\
\text { c.id }\end{array}$ & $\begin{array}{l}\text { Menampila } \\
\text { kn "Data } \\
\text { anda sudah } \\
\text { disimpan } \\
\text { silahkan } \\
\text { login } \\
\text { terlebih } \\
\text { dahulu } \\
\text { untuk } \\
\text { berbelanja" }\end{array}$ & $\begin{array}{l}\text { Sesuai } \\
\text { harapan }\end{array}$ & Valid \\
\hline
\end{tabular}




\section{KESIMPULAN}

Berdasarkan hasil perancangan dan pengolahan data yang telah dilakukan, menghasilkan sebuah aplikasi berbasis web yang dapat digunakan sebagai sarana promosi serta transaksi. Kesimpulannya adalah :

1. Website Fortun Barokah Karawang ini sebagai sarana untuk mempromosikan serta bertransaksi secara mudah dalam hak akses yang lebih luas kepada masyarakat.

2. Website Fortun Barokah Karawang ini mempermudah pengunjung dalam melihat dan mencari informasi tentang perlengkapan tidur khususnya yang sudah ter up to date.

3. Dengan adanya website Fortun Barokah Karawang ini memperluas pemasaran perlengkapan tidur karena dapat diakses kapan saja dan dimana saja.

\section{DAFTAR PUSTAKA}

Ardhana, Y. M. K. (2012) 'Dengan PHP: Menyelesaikan Website 30 Juta Rupiah', Jasakom, Jakarta. Binanto, I. (2010) Multimedia digital-dasar teori dan pengembangannya. Penerbit Andi. Fathansyah, I. (2004) 'Buku Teks Komputer Basis Data', Informatika, Bandung. Ichwan, M. (2011) 'Pemrograman Basis data delphi 7 dan Mysql', Bandung: Informatika. Janner, S. (2010) 'Rekayasa perangkat lunak', Yogyakarta: Penerbit Andi.

Jogiyanto, H. M. (2009) 'Sistem Informasi Teknologi', Yogyakarta: ANDI offset.

Kroenke's, D. M. (2006) 'Database Processing'.

Rosa, A. S. (no date) 'Shalahudin 2013 Rekayasa Perangkat Lunak Terstruktur dan Berorientasi Objek'. Bandung: Informatika.

Rosa, A. S. and Shalahuddin, M. (2013) 'Rekayasa perangkat lunak terstruktur dan berorientasi objek', Bandung: informatika.

Sadeli, M. (2013) 'Toko Baju Online dengan PHP dan MySQL', Palembang: Maxikom.

Sugiarto, M. (2009) Google Cheat. Elex Media Komputindo.

Sutarman (2009) Pengantar teknologi informasi. Jakarta: Bumi Aksara.

Suyanto, A. H. (2008) 'Step by Step Web Design Theory and Practice Edisi II', Yogyakarta: Andi Publisher.

Virgi, A. H. (2011) 'Cepat Mahir Pemograman Web Dengan PHP dan MySQL', Jakarta: PT. Prestasi Pustakaraya.

Wicaksono, Y. (2008) Membangun Bisnis Online dg Mambo+ CD. Elex Media Komputindo. 